\title{
Kandungan Fraksi Serat Pelepah Sawit Hasil Biodelignifikasi Menggunakan Kapang Phanerochaete chrysosporium dengan Penambahan Mineral Ca dan Mn
}

\section{Content of Fiber Fraction of Biodelignificated Palm Limb Using Phanerochaete chrysosporium Mold with Ca and Mn Addition}

\author{
D. Febrina ${ }^{1}$, N. Jamarun ${ }^{2}$, M. Zain ${ }^{2}$ dan Khasrad ${ }^{2}$ \\ ${ }^{1}$ Fakultas Pertanian dan Peternakan Universitas Islam Negeri Sultan Syarif Kasim Riau \\ ${ }^{2}$ Fakultas Peternakan Universitas Andalas \\ e-Mail : hanna_suska@yahoo.com \\ (Diterima: 7 2015; Disetujui: 27 2015)
}

\begin{abstract}
ABSTRAK
Penelitian ini bertujuan untuk mengetahui pengaruh penambahan mineral $\mathrm{Ca}$ dan $\mathrm{Mn}$ dalam proses biodelignifikasi pelepah sawit menggunakan kapang Phanerochaete chrysosporium terhadap kandungan fraksi serat. Penelitian menggunakan Rancangan Acak Lengkap (RAL) pola Faktorial 3 x 3 dengan dua ulangan: Faktor A adalah dosis mineral Ca $(1.000 ; 2.000$ dan 3.000 ppm). Faktor B adalah dosis mineral Mn (50, 100 dan 150 ppm). Fermentasi berlangsung selama 10 hari. Peubah yang diukur adalah kandungan NDF, ADF, hemiselulosa, selulosa dan lignin. Hasil penelitian menunjukkan interaksi antara mineral Ca dan Mn mempengaruhi kandungan NDF, selulosa dan lignin. Penambahan $2.000 \mathrm{ppm}$ Ca dan $150 \mathrm{ppm}$ Mn pada biodelignifikasi pelepah sawit menggunakan kapang Phanerochaete chrysosporium memberikan hasil terbaik karena menghasilkan kandungan lignin terendah yaitu $22,4 \%$.
\end{abstract}

Kata kunci : pelepah sawit, Phanerochaete chrysosporium, fraksi serat, $\mathrm{Ca}, \mathrm{Mn}$

\section{ABSTRACT}

The study was aimed at evaluating the effects of calcium and manganese addition during frond biodelignification by Phanerochaete chrysosporium to the content of fiber fractions of Palm Limb. The Completely Randomized Design was used comparing two factors as treatments and each treatment was repeated two times. The factors were Ca dose (1.000, 2.000 and $3.000 \mathrm{ppm})$ and $\mathrm{Mn}$ dose (50, 100 and $150 \mathrm{ppm})$. The fermentation process carried out within 10 days. Measured variables were the content of NDF, ADF, hemicellulose, cellulose and lignin. The results indicated that the was an interaction between minerals Ca and Mn affecting the content of NDF, cellulose and lignin. The addition of $2.000 \mathrm{ppm} \mathrm{Ca}$ and $150 \mathrm{ppm} \mathrm{Mn}$ during oil palm frond biodelignification by Phanerochaete chrysosporium resulted in the best option due to its lowest lignin content production (22.4\%).

Keywords : palm frond, phanerochaete chrysosporium, fiber fraction, minerals

\section{PENDAHULUAN}

Salah satu bahan pakan alternatif non konvensional yang potensial dimanfaatkan sebagai pakan berasal dari limbah perkebunan kelapa sawit. Indonesia merupakan produsen kelapa sawit terbesar di dunia, dengan luas tanam tahun 2014 mencapai $10.956 .231 \mathrm{Ha}$ (Kementerian Pertanian, 2014).

Integrasi perkebunan kelapa sawit dengan peternakan merupakan peluang pengembangan usaha peternakan di Indonesia. Pemanfaatan pelepah sawit sebagai pakan masih terbatas karena tingginya kandungan 
lignin sehingga sulit didegradasi baik secara kimia dan enzimatik (Ohkuma et al., 2001). Pelepah kelapa sawit mempunyai kandungan lignin 30,18\% (Febrina et al., 2014); kecernaan bahan kering $40 \%$ (Kawamoto et al., 2001) dan kandungan energi 4,9-5,6 MJ $\mathrm{ME} / \mathrm{kg}$ DM (Alimon, 2005; Zahari dan Alimon, 2005).

Kapang Phanerochaete chrysosporium merupakan mikroorganisme ligninolitik paling efisien mendegradasi lignin yang berasal dari kelas Basidiomycetes (Kirk 1993; May et al., 1997; Crawford, 1987). Pertumbuhan kapang ini dipengaruhi oleh ketersediaan mineral dalam substrat. Wuyep et al. (2003) menyatakan $\mathrm{Mn}$ dan $\mathrm{Ca}$ dapat memacu pertumbuhan dan perpanjangan miselia. Penambahan $\mathrm{Ca}$ ke dalam media secara nyata meningkatkan pertumbuhan kapang (Chung, 2003); penambahan $\mathrm{Mn}$ ke dalam substrat mampu meningkatkan degradasi lignin (Kerem dan Hadar, 1997) dan kecernaan bahan kering substrat (Kerem dan Hadar, 1995).

Penambahan Ca 1.190 ppm dan Mn 100 ppm menghasilkan pertumbuhan maksimum pada kapang (Nelson (2011); diameter koloni $8,39 \mathrm{~cm}$, berat kering miselia $17,49 \mathrm{mg}$, aktivitas enzim lignin peroksidase 5,95 $\mathrm{U} \mathrm{g}^{-1}$ berat kering miselia dan aktivitas enzim mangan peroksidase $5,68 \mathrm{U} \mathrm{g}^{-1}$ berat kering miselia (Suparjo, 2010). Fermentasi batang kapas menggunakan kapang Phanerochaete chrysosporium dapat mendegradasi lignin pada lama fermentasi 4-10 hari (Shi et al., 2009).

Biodelignifikasi pelepah sawit menggunakan kapang Phanerochaete chrysosporium mampu menurunkan kandungan lignin $27,34 \%$ dengan penambahan mineral $\mathrm{Ca}$ (Febrina, 2014) dan 29,89\% dengan penambahan mineral Mn (Febrina et al., 2014). Biodelignifikasi pelepah sawit menggunakan kapang Phanerochaete chrysosporium ditambah mineral $\mathrm{Ca}$ dan $\mathrm{Mn}$ belum dilaporkan. Bertitik tolak dari uraian di atas telah dilakuan penelitian untuk mengevaluasi pengaruh penambahan mineral $\mathrm{Ca}$ dan $\mathrm{Mn}$ dalam proses biodelignifikasi pelepah sawit menggunakan kapang Phanerochaete chrysosporium terhadap kandungan fraksi serat. Kombinasi mineral Ca dan Mn pada biodelignifikasi pelepah sawit menggunakan kapang Phanerochaete chrysosporium diduga mampu memicu pertumbuhan kapang dan produksi enzim ligninolitik yang lebih banyak sehingga mampu menurunkan kandungan lignin dalam jumlah yang lebih besar.

\section{METODE}

\section{Bahan dan Alat Penelitian}

Bahan penelitian adalah pelepah sawit, medium biakan (Potato Dextrose Agar), kapang Phanerochaete chrysosporium, mineral $\mathrm{Ca}$ dan $\mathrm{Mn}$ berasal dari mineral $\mathrm{CaCl}_{2}$ dan $\mathrm{MnSO}_{4} \cdot \mathrm{H}_{2} \mathrm{O}$, serta zat-zat kimia untuk analisis Van Soest.

Peralatan yang digunakan adalah laminar flow, timbangan digital, tabung Erlenmeyer, tabung reaksi, fibertec, oven, tanur, botol selai, sendok teh, autoclave, inkubator.

\section{Metoda Penelitian}

Penelitian menggunakan Rancangan Acak Lengkap (RAL) pola faktorial (3 x 3 ) dengan dua ulangan. :

Faktor A adalah dosis mineral $\mathrm{Ca}$, yaitu :

$$
\begin{aligned}
\mathrm{A} 1= & \begin{array}{l}
\text { Pelepah Sawit }+ \text { Phanerochaete } \\
\text { chrysosporium }+\mathrm{Ca} 1.000 \text { ppm. }
\end{array} \\
\mathrm{A} 2= & \begin{array}{l}
\text { Pelepah Sawit }+ \text { Phanerochaete } \\
\text { chrysosporium }+\mathrm{Ca} 2.000 \text { ppm. }
\end{array} \\
\mathrm{A} 3= & \begin{array}{l}
\text { Pelepah Sawit }+ \text { Phanerochaete } \\
\text { chrysosporium }+\mathrm{Ca} 3.000 \text { ppm. }
\end{array}
\end{aligned}
$$

Faktor B adalah dosis mineral Mn, yaitu :

$\mathrm{B} 1=$ Pelepah Sawit + Phanerochaete chrysosporium + Mn 50 ppm.

$\mathrm{B} 2=$ Pelepah Sawit + Phanerochaete chrysosporium + Mn 100 ppm.

$\mathrm{B} 3=$ Pelepah Sawit + Phanerochaete chrysosporium + Mn 150 ppm.

Pelepah sawit yang digunakan adalah dua pertiga (2/3) bagian depan (mempunyai 150-200 helai daun) kemudian dicacah menggunakan Leaf Chopper. Kapang Phanerochaete chrysosporium ditumbuhkan pada media Potato Dextrose Agar (PDA) pada suhu $30^{\circ} \mathrm{C}$ selama 7 hari. Pembuatan inokulum 
Phanerochaete chrysosporium menggunakan substrat yaitu dedak padi sebanyak $25 \mathrm{~g}$ yang ditambahkan aquades sehingga kadar airnya mencapai $70 \%$, disterilkan dengan autoclave pada suhu $121^{\circ} \mathrm{C}$ selama 15 menit kemudian didinginkan hingga mencapai suhu kamar, hasil ini disebut dengan substrat steril.

Kapang Phanerochaete chrysosporium yang sudah tumbuh pada media PDA sebanyak satu (1) testube diinokulasikan ke dalam 3 botol selai yang telah berisi dedak padi yang sudah disterilkan (masing-masing botol berisi $25 \mathrm{~g}$ dedak padi), lalu diinkubasi pada suhu kamar selama 7 hari, setelah kapang tumbuh optimal maka inokulum siap digunakan untuk proses delignifikasi pelepah sawit.

Pelepah sawit ditimbang, selanjutnya ditambah aquades sehingga kadar airnya mencapai $70 \%$ lalu ditambahkan mineral $\mathrm{Ca}$ dan Mn sesuai perlakuan dan disterilkan dalam autoclave pada suhu $121^{\circ} \mathrm{C}$ selama 15 menit, kemudian didinginkan. Setelah dingin pelepah sawit diinokulasi dengan kapang Phanerochaete chrysosporium sebanyak 10\% dari jumlah substrat (pelepah sawit) (Crueger dan Crueger, 1984), diaduk merata kemudian diinkubasi selama 10 hari berdasarkan (Mariani, 2014) dan (Rahayu, 2014). Setelah proses fermentasi selesai (10 hari), produk fermentasi kemudian ditimbang berat segarnya dan dikeringkan pada suhu $60^{\circ} \mathrm{C}$ selama 48 jam kemudian dianalisis

Data dianalisis menggunakan analisis ragam dan pengujian nilai tengah perlakuan menggunakan uji jarak berganda Duncan. Peubah yang diukur adalah kandungan fraksi serat meliputi : kandungan NDF, ADF, hemiselulosa, selulosa dan lignin.

\section{HASIL DAN PEMBAHASAN}

Pengaruh penambahan mineral $\mathrm{Ca}$ dan $\mathrm{Mn}$ pada biodelignifikasi pelepah sawit menggunakan kapang Phanerochaete chrysosporium terlihat pada Tabel 1 .

Terjadi perubahan fraksi serat pelepah sawit setelah proses biodelignifikasi menggunakan kapang Phanerochaete chrysosporium ditambah mineral $\mathrm{Ca}$ dan $\mathrm{Mn}$ dibandingkan tanpa proses biodelignifikasi, hal ini menunjukkan selama proses biodelignifikasi terjadi perombakan ligno-selulosa dan lignohemiselulosa oleh kapang selanjutnya kapang dapat memanfaatkan isi sel untuk pertumbuhan dan perkembangannya. Erikson (1993) menyatakan selama pertumbuhannya kapang Phanerochaete chrysosporium yang diinokulasikan pada batang kapas tidak hanya mendegradasi lignin, tetapi juga mengkonsumsi selulosa dan hemiselulosa sebagai sumber karbon.

Interaksi mineral $\mathrm{Ca}$ dan $\mathrm{Mn}$ secara nyata $(\mathrm{P}<0,05)$ mempengaruhi kandungan NDF pelepah sawit hasil biodelignifikasi oleh kapang Phanerochaete chrysosporium. Kandungan NDF tertinggi yaitu $89,00 \%$ pada perlakuan $1.000 \mathrm{ppm} \mathrm{Ca}+100 \mathrm{ppm}$ Mn tidak berbeda $(\mathrm{P}>0,05)$ dibandingkan perlakuan $2.000 \mathrm{ppm} \mathrm{Ca}+50 \mathrm{ppm} \mathrm{Mn} ; 3.000 \mathrm{ppm} \mathrm{Ca}+$ 100 ppm Mn; 1.000 ppm Ca +150 ppm Mn dan $2.000 \mathrm{ppm} \mathrm{Ca}+150 \mathrm{ppm}$ Mn. Tingginya kandungan NDF pada perlakuan 1.000 ppm $\mathrm{Ca}+100$ ppm Mn menunjukkan penambahan $1.000 \mathrm{ppm}$ Ca belum mampu memicu partumbuhan dan perpanjangan miselia kapang Phanerochaete chrysosporium sehingga kapang belum mampu merombak ikatan lignoselulosa dan lignohemiselulosa.

Kalsium berperan dalam pertumbuhan dan pembentukan cabang hifa kapang (Jackson dan Heath, 1993); Nelson (2011) melaporkan kapang Phanerochaete chrysosporium yang ditumbuhkan pada media kulit buah kakao mencapai pertumbuhan maksimal dengan penambahan 1.190 ppm Ca. Penambahan Mn sampai 100 ppm belum mampu memicu produksi enzim ligninolitik oleh kapang Phanerochaete chrysosporium sehingga belum mampu memecah ikatan lignoselulosa dan lignohemiselulosa, seperti yang dilaporkan Silva et al., (2008) supplementasi Mn 183 ppm pada Eucalyptus dapat memicu produksi Lignin Peroksidase (LiP).

Peningkatan dosis $\mathrm{Ca}$ dari $1.000 \mathrm{ppm}$ menjadi $3.000 \mathrm{ppm}$ dan $\mathrm{Mn}$ dari $100 \mathrm{ppm}$ menjadi $150 \mathrm{ppm}$ menurunkan kandungan 
$\mathrm{NDF}$, terlihat pada perlakuan $3.000 \mathrm{ppm} \mathrm{Ca}+$ $150 \mathrm{ppm}$ Mn menghasilkan kandungan NDF terendah yaitu $81,00 \%$ nyata berbeda $(\mathrm{P}<0,05)$ dibandingkan perlakuan $1.000 \mathrm{ppm} \mathrm{Ca}+100$ ppm Mn dan 1.000 ppm Ca + 150 ppm Mn. Terjadi penurunan kandungan NDF seiring dengan peningkatan dosis Ca dari 1.000 ppm menjadi $3.000 \mathrm{ppm}$ diduga dosis $\mathrm{Ca}$ sudah optimal sehingga dapat memicu perkembangan hifa kapang dan menstimulasi produksi enzim ligninolitik sehingga menurunkan kandungan NDF, seperti yang dilaporkan Wuyep et al. (2003) penambahan 2.400-3.200 ppm $\mathrm{Ca}$ menghasilkan pertumbuhan dan aktivitas enzim ligninolitik terbaik pada $L$. squarrosulus dan P.atroumbonata

Peningkatan dosis Mn dari 100 ppm menjadi $150 \mathrm{ppm}$ dapat memicu produksi enzim ligninolitik terutama $\mathrm{MnP}$ sehingga kapang mampu memecah ikatan lignoselulosa dan lignohemiselulosa serta menurunkan kandungan NDF. $\mathrm{Mn}^{2+}$ adalah efektor spesifik yang mendorong produksi MnP (Zhao et al., 1996); konsentrasi $\mathrm{Mn}^{2+}$ yang tinggi membantu produksi MnP (Bonnarme dan Jeffrics, 1990); penambahan $\mathrm{Mn}^{2+}$ sebanyak $900 \mathrm{mg} / \mathrm{l}$ meningkatkan pembentukan MnP (Rothschild et al., 1999).

Penambahan $\mathrm{Ca}, \mathrm{Mn}$ dan interaksi $\mathrm{Ca}$ dan Mn pada biodelignifikasi pelepah sawit oleh kapang Phanerochaete chrysosporium tidak berpengaruh $(\mathrm{P}>0,05)$ terhadap kandungan ADF.

Tidak ada pengaruh penambahan $\mathrm{Ca}$ dan $\mathrm{Mn}$ serta interaksi $\mathrm{Ca}$ dan $\mathrm{Mn}$ terhadap kandungan ADF pelepah sawit hasil biodelignifikasi menunjukkan penambahan $\mathrm{Ca}$ dan Mn pada biodelignifikasi pelepah sawit hanya mampu merenggangkan ikatan antara dinding sel dengan isi sel (lignoselulosa dan lingohemi-selulosa). Merenggangnya ikatan lingoselulosa dan lignohemiselulosa menyebabkan selulosa dapat dimanfaatkan oleh mikroorganisme sebagai sumber energi, tetapi belum dapat menurunkan kandungan lignin dan ADF. Hal ini menunjukkan ADF merupakan bagian dinding sel tanaman yang sulit dicerna karena memiliki ikatan rangkap. Van Soest (1994) menyatakan ADF terdiri dari selulosa, lignin dan silika, bagian yang mudah dicerna adalah selulosa, sedangkan lignin dan silika sulit dicerna karena memiliki ikatan rangkap (Sutardi, 1980). Nilai ADF berkorelasi negatif dengan kecernaan pakan semakin tinggi kandungan ADF dalam pakan akan menurunkan kecernaannya (Shroeder, 2004).

Kandungan hemiselulosa pelepah sawit hasil biodelignifikasi berkisar 14,68723,667\%. Penambahan Ca, Mn dan interaksi antara $\mathrm{Ca}$ dan $\mathrm{Mn}$ tidak memberikan pengaruh terhadap kandungan hemiselulosa pelepah sawit hasil biodelignifikasi.

Penambahan Ca dan Mn tidak memberikan pengaruh terhadap kandungan hemiselulosa diduga karena penambahan $\mathrm{Ca}$ dan $\mathrm{Mn}$ juga tidak memberikan pengaruh terhadap kandungan ADF. Hemiselulosa diperoleh dari pengurangan NDF dengan ADF. Perlakuan A1B2 (1.000 ppm Ca dan $100 \mathrm{Mn})$ menghasilkan kandungan NDF tertinggi sehingga menghasilkan kandungan hemiselulosa tertinggi juga. Tingginya kandungan hemiselulosa akan menyediakan sumber energi yang mudah dimanfaatkan oleh mikroba rumen dalam jumlah yang lebih banyak.

Semakin tinggi kandungan hemiselulosa maka akan semakin banyak sumber energi yang mudah dimanfaatkan oleh mikroba rumen, hal ini disebabkan hemiselulosa merupakan struktur karbohidrat kompleks yang tersusun atas polimer pentosa (xylosa, arabinosa), heksosa (mannosa, glukosa, galaktosa) dan asam gula (Church dan Ponds, 1982; Dashtban et al., 2009; Hendriks dan Zeeman, 2009); hemiselulosa mempunyai berat molekul lebih kecil dibandingkan selulosa dengan cabang rantai pendek terdiri dari gula berbeda (Perez et al., 2002) sehingga lebih mudah dihidrolisis (Hendriks dan Zeeman, 2009). Hidrolisis hemiselulosa dapat dilakukan oleh beberapa mikroorganisme yang mampu menggunakan gula sebagai substratnya sehingga terjadi pemecahan hemiselulosa pada tahap awal fermentasi dan bakteri asam laktat akan merombak hemiselulosa setelah karbohidrat habis terpakai dan membentuk asam organik (McDonald, 2010). Terjadi penurunan hemise- 
Tabel.1. Pengaruh penambahan mineral Ca dan Mn pada biodelignifikasi pelepah sawit menggunakan kapang Phanerochaete chrysosporium terhadap kandungan fraksi serat

\begin{tabular}{|c|c|c|c|c|}
\hline \multirow{2}{*}{$\begin{array}{c}\mathrm{A} \\
\text { Mineral } \mathrm{Ca}(\mathrm{ppm})\end{array}$} & \multicolumn{4}{|c|}{ B Mineral Mn (ppm) } \\
\hline & B1 (50) & B2 (100) & B3 (150) & Rataan \\
\hline \multicolumn{5}{|c|}{ Kandungan NDF } \\
\hline A1 (1.000) & $82,000 \pm 0^{b}$ & $89,000 \pm 4,24^{\mathrm{a}}$ & $85,000 \pm 1,41^{\mathrm{a}}$ & 84,667 \\
\hline A2 (2.000) & $85,000 \pm 1,41^{\mathrm{ab}}$ & $82,000 \pm 2,82^{b}$ & $83,000 \pm 1,41^{\mathrm{ab}}$ & 83,333 \\
\hline A3 (3.000) & $82,196 \pm 2,55^{\mathrm{b}}$ & $85,000 \pm 4,24^{\mathrm{ab}}$ & $81,000 \pm 1,41^{\mathrm{b}}$ & 82,732 \\
\hline Rataan & 83,065 & 85,333 & 82,333 & \\
\hline \multicolumn{5}{|c|}{ Kandungan ADF } \\
\hline A1 (1.000) & $65,000 \pm 1,41$ & $65,334 \pm 1,88$ & $68,314 \pm 0,44$ & 66,216 \\
\hline A2 (2.000) & $65,334 \pm 1,88$ & $65,000 \pm 4,24$ & $63,579 \pm 0,59$ & 64,638 \\
\hline A3 (3.000) & $63,000 \pm 1,41$ & $65,392 \pm 5,05$ & $66,000 \pm 0$ & 64,797 \\
\hline Rataan & 64,445 & 65,242 & 65,964 & \\
\hline \multicolumn{5}{|c|}{ Kandungan Hemiselulosa } \\
\hline A1 (1.000) & $17,000 \pm 1,41$ & $23,667 \pm 6,12$ & $14,687 \pm 0,97$ & 18,451 \\
\hline A2 (2.000) & $19,667 \pm 0,47$ & $17,000 \pm 1,41$ & $19,421 \pm 2,00$ & 18,696 \\
\hline A3 (3.000) & $19,196 \pm 3,96$ & $19,608 \pm 9,29$ & $15,000 \pm 1,41$ & 17,935 \\
\hline Rataan & 18,621 & 20,092 & 16,369 & \\
\hline \multicolumn{5}{|c|}{ Kandungan Selulosa } \\
\hline A1 (1.000) & $40,000 \pm 0^{\mathrm{a}}$ & $37,298 \pm 1,83^{\mathrm{ab}}$ & $41,588 \pm 0,58^{\mathrm{a}}$ & 39,629 \\
\hline A2 (2.000) & $39,588 \pm 2,24^{\mathrm{a}}$ & $36,000 \pm 2,82^{\mathrm{ab}}$ & $39,298 \pm 0,99^{\mathrm{a}}$ & 38,295 \\
\hline A3 (3.000) & $37,000 \pm 1,41^{\mathrm{ab}}$ & $30,831 \pm 7,60^{\mathrm{b}}$ & $40,000 \pm 0^{\mathrm{a}}$ & 35,944 \\
\hline Rataan & $38,863^{\mathrm{a}}$ & $34,710^{\mathrm{b}}$ & $40,295^{\mathrm{a}}$ & \\
\hline \multicolumn{5}{|c|}{ Kandungan Lignin } \\
\hline A1 (1.000) & $23,000 \pm 1,41^{\text {cd }}$ & $27,158 \pm 1,19^{b}$ & $24,475 \pm 1,05^{\mathrm{c}}$ & $24,968^{\mathrm{ab}}$ \\
\hline A2 (2.000) & $23,765 \pm 0,33^{\text {cd }}$ & $28,000 \pm 0^{\mathrm{ab}}$ & $22,404 \pm 0,57^{\mathrm{d}}$ & $24,723^{\mathrm{a}}$ \\
\hline A3 (3.000) & $25,000 \pm 1,41^{\mathrm{c}}$ & $29,310 \pm 0^{\mathrm{a}}$ & $24,000 \pm 0^{\mathrm{cd}}$ & $26,103^{\mathrm{a}}$ \\
\hline Rataan & $23,922^{\mathrm{b}}$ & $28,156^{\mathrm{a}}$ & $23,716^{\mathrm{b}}$ & \\
\hline
\end{tabular}

Keterangan : superskrip yang berbeda pada baris dan kolom yang sama menunjukkan perngaruh perlakuan berbeda nyata $(\mathrm{P}<0,05)$.

lulosa 55\% pada fermentasi pulp produk samping gula beet menggunakan kapang $T$. reesei (Iconomou et al., 1998).

Kandungan selulosa pada dinding sel tanaman berkisar 35\% (Lynd et al., 2002) sampai 45\% (Perez et al., 2002) dari berat kering tanaman. Kandungan selulosa pelepah sawit sebelum biodelignifikasi adalah 39,63\%, terjadi perubahan kandungan selulosa setelah biodelignifikasi menggunakan kapang Phanerochaete chrysosporium dengan kandungan selulosa berkisar 33,69\%-41,60\% .

Terjadi perubahan kandungan selulosa pelepah sawit setelah mengalami proses biodelignifikasi menunjukkan kapang Phanerochaete chrysosporium mempunyai aktivitas enzim selulase. Phanerochaete chrysosporium menghasilkan enzim selulase dengan aktivitas menyerupai endogluconases (EGs) exocellobiohydrolases (CBHs) (Broda et al., 1996) dan 3 tipe $\beta$-glucosidases tergantung sumber karbon yang tersedia (Lymar et al., 1995; Wan dan Li, 2012). Phanerochaete chrysosporium merupakan kapang pendegradasi lignin yang bersifat selektif, yaitu lignin didegradasi dengan sedikit kehilangan selulosa (Blanchette et al., 1991); CMCase merupakan salah satu enzim yang berperan dalam proses perombakan selulosa (Shi et al., 2006), puncak produksi CMCase oleh kapang Phanerochaete chrysosporium tercapai pada hari ke 12 (Zeng et al., 2010)

Penambahan 2.000 ppm Ca dan 150 ppm Mn menghasilkan kandungan selulosa tertinggi yaitu $41,60 \%$, hal ini diduga 
penambahan Ca 2.000 ppm mampu memicu dan memperpanjang hifa kapang sehingga kapang mampu menembus ikatan amorf pada selulosa, yang menyebabkan ikatan antara selulosa dengan lignin terlepas. Supplementasi $\mathrm{Mn}^{2+}$ secara nyata meningkatkan aktivitas enzim selulase (Shi et al., 2008); supplementasi $\mathrm{Mn}^{2+}$ pada fermentasi batang kapas menggunakan kapang Phanerochaete chrysosporium menghasilkan aktivitas enzim selulase yang lebih tinggi (Shi et al., 2009). Selulosa mengandung 50-90\% bagian kristalin dan sisanya amorf (Jacobsen dan Wyman, 2000), bagian kristalin lebih susah didegradasi dibandingkan bagian amorf (Widiyanto et al., 2015); jika bagian amorf dihidrolisis maka bagian ini akan melarut (Mc Donal et al., 2010).

Kandungan selulosa terendah yaitu $33,69 \%$ terdapat pada perlakuan $3.000 \mathrm{ppm}$ $\mathrm{Ca}$ dan 100 ppm Mn. Menurunnya kandungan selulosa seiring dengan meningkatnya konsentrasi Ca dari 2.000 ppm menjadi 3.000 ppm diduga hifa kapang mengalami keracunan akibat tingginya konsentrasi $\mathrm{Ca}$, sesuai pendapat Jackson dan Heath (1993) konsentrasi Ca eksternal yang tinggi dapat menghambat perpanjangan ujung hifa kapang karena interaksi $\mathrm{Ca}^{2+}$ dengan dinding sel menyebabkan rigiditas dinding sel atau karena respon keracunan terhadap konsentrasi Ca sitoplasma yang tinggi.

Kandungan lignin pelepah sawit sebelum biodelignifikasi adalah 30,18\%. Proses biodelignifikasi pelepah sawit menggunakan kapang Phanerochaete chrysosporium ditambah mineral $\mathrm{Ca}$ dan $\mathrm{Mn}$ menurunkan kandungan lignin 2,88\%-25,77\% (kandungan lignin setelah biodelignifikasi adalah $22,40 \%$ $29,31 \%$ ). Terjadi penurunan kandungan lignin setelah proses biodelignifikasi menunjukkan kapang Phanerochaete chrysosporium mempunyai aktivitas enzim ligninolitik. Kapang Phanerochaete chrysosporium berperan penting dalam proses perombakan lignin karena menghasilkan enzim pendegradasi lignin, yaitu Lignin Peroksidase (LiP) dan Mangan Peroksidase (MnP) (Srebotnik et al., 1994); mendegradasi lignin secara selektif (de Koker et al., 2003) yaitu lignin didegradasi dengan sedikit kehilangan selulosa (Blanchette et al.,1991); merupakan model dalam pengembangan dan pemahaman sistem produksi enzim ligninolitik karena kapang ini menghasilkan enzim ligninolitik yang lebih lengkap dibanding strain lain (Singh dan Chen, 2008).

Pertumbuhan kapang Phanerochaete chrysosporium dan aktivitas enzim ligninolitik salah satunya dipengaruhi oleh ketersediaan nutrien dalam substrat. Terjadi peningkatan akses enzim ligninolitik dengan penambahan $\mathrm{Ca}$ dan $\mathrm{Mn}$ sehingga dapat memutus ikatan lignoselulosa dinding sel. Penambahan $\mathrm{Ca}$ dan Mn mampu menstimulasi pertumbuhan dan perpanjangan miselia kapang. Miselia kapang akan menembus jaringan substrat sehingga lebih banyak enzim ligninase yang dihasilkan sehingga menurunkan lignin dengan jumlah lebih banyak. Brown et al. (1990) menyatakan produksi enzim lignolitik oleh kapang Phanerochaete chrysosporium dapat ditingkatkan dengan penambahan $\mathrm{Ca}$ dan $\mathrm{Mn}$. Mangan memacu pemecahan lignin secara efektif oleh fungi (Blanchette, 1984; Kerem dan Hadar, 1995). Penurunan kandungan lignin akan memudahkan pemecahan struktur kristal selulosa sehingga memudahkan akses substrat oleh enzim hidrolitik (Sun dan Cheng, 2002).

Kandungan lignin terendah terdapat pada perlakuan dengan penambahan 2.000 ppm Ca dan 150 ppm $\mathrm{Mn}$, hal ini menunjukkan interaksi $\mathrm{Ca}$ dan $\mathrm{Mn}$ mampu menstimulasi kapang untuk menghasilkan enzim ligninolitik yang optimal sehingga terjadi penurunan kandungan lignin tertinggi yaitu $25,77 \%$ (terjadi penurunan kandungan lignin dari 30,18\% menjadi 22,4\%). Fermentasi pelepah sawit oleh kapang Phanerochaete chrysosporium dengan lama pemeraman 10 hari menghasilkan penurunan kandungan lignin tertinggi yaitu $26,79 \%$ dengan penambahan Ca 2.000 ppm (Rahayu, 2014) dan $29,88 \%$ dengan penambahan $100 \mathrm{ppm} \mathrm{Mn}$ (Mariani, 2014). Kombinasi 100 ppm Mn dan 1.190 ppm Ca memberikan hasil terbaik pada aktivitas enzim LiP dan MnP pada fermentasi 
kulit buah kakao dengan kapang Phanerochaete chrysosporium (Suparjo, 2010).

Tingginya penurunan lignin yaitu $25,77 \%$ pada perlakuan dengan penambahan $2.000 \mathrm{ppm} \mathrm{Ca}$ dan $150 \mathrm{ppm}$ Mn diduga penambahan $\mathrm{Mn}$ pada proses biodelignifikasi menyebabkan tingginya produksi enzim $\mathrm{MnP}$, seperti yang dinyatakan Wan dan Li (2012) supplementasi $\mathrm{Mn}^{2+}, \mathrm{H}_{2} \mathrm{O}_{2}$, dan senyawa aromatik, merangsang sekresi enzim ligninolitik dan degradasi lignin. Kapich et al. (2004) degradasi lignin berkorelasi dengan produksi $\mathrm{MnP}$ dan produksi MnP tergantung dari konsentrasi Mn (Bonnarme and Jeffries, 1990; Brown et al., 1990),

Waktu inkubasi mempengaruhi produksi enzim ligninolitik dan degradasi lignin (Shi et al., 2009). Phanerochaete chrysosporium adalah kapang pelapuk putih yang tumbuh dengan cepat, hanya dibutuhkan beberapa hari atau minggu untuk mendegradasi substrat dan proses degradasi lignin dan hemiselulosa terjadi secara selektif (Keller et al., 2003). Proses biodelignifikasi pelepah sawit selama 10 hari menggunakan kapang Phanerochaete chrysosporium ditambah $\mathrm{Ca} 2.000 \mathrm{ppm}$ dan $150 \mathrm{ppm} \mathrm{Mn}$ diduga telah memicu kapang untuk memproduksi enzim ligninolitik yang optimal sehinggga mampu mendegadasi lignin. Hal ini didukung peneliti lain seperti Zeng et al. (2010) puncak akitivitas MnP terjadi pada hari ke 10 dan 21; aktivitas enzim MnP tertinggi setelah 6 hari inkubasi menggunakan kapang Phanerochaete chrysosporium (Urek dan Pazarlioglu, 2005); degradasi lignin meningkat setelah 7 hari fermentasi (Kumar et al., 2006); degradasi lignin terjadi pada hari ke 4-10 dan tingkat delignifikasi bervariasi selama 1-14 hari tergantung dari proses metabolisme kapang (Shi et al., 2009); periode degradasi lignin pada hari ke 4-7 berhubungan dengan tingginya produksi ligninase (Kirk et al., 1978; Jäger et al., 1985);

Penambahan Ca 3.000 ppm dan Mn 100 ppm pada biodelignifikasi pelepah sawit menggunakan kapang Phanerochaete chrysosporium hanya mampu menurunkan kandungan lignin 2,88\% (menurun dari $30,18 \%$ menjadi $29,31 \%$ ) sehingga menghasilkan kandungan lignin tertinggi dibandingkan perlakuan lain yaitu $29,310 \%$, hal ini menunjukkan aktivitas enzim ligninolitik yang dihasilkan kapang Phanerochaete chrysosporium lebih rendah dibandingkan perlakuan lain sehingga penurunan kandungan lignin hanya mencapai 2,88\%. Shi et al. (2009) menyatakan degradasi lignin dikaitkan dengan aktivitas enzim ligninolitik; keseimbangan mineral $\mathrm{Mg}^{2+}, \mathrm{Ca}^{2+}$ dan $\mathrm{Mn}^{2+}$ sangat penting untuk produksi ligninase (Kirk et al.,1978 dan Brown et al.,1990).

Penurunan kandungan lignin pada penelitian ini yaitu $25,77 \%$ hampir sama yang dilaporkan Zhi dan Wang (2013) penurunan lignin $28,5 \pm 1,3 \%$ pada fermentasi jerami gandum menggunakan kapang Phanerochaete chrysosporium; lebih tinggi dibandingkan Laconi (1998) penurunan lignin 18,36\%pada fermentasi kulit buah kakao oleh kapang Phanerochaete chrysosporium tetapi lebih rendah dibandingkan Suparjo (2010) kandungan lignin menurun 29,09\%-38,61\% pada fermentasi kulit buah kakao dengan kapang Phanerochaete chrysosporium ditambah mineral $\mathrm{Ca}^{2+}$ dan $\mathrm{Mn}^{2+}$ serta Imsya (2013) kehilangan lignin $17,34-49,47 \%$ pada fermentasi pelepah sawit menggunakan kapang Phanerochaete chrysosporium

\section{KESIMPULAN}

Penambahan 2.000 ppm Ca dan 150 ppm Mn pada biodelignifikasi pelepah sawit menggunakan kapang Phanerochaete chrysosporium memberikan hasil terbaik karena menghasilkan kandungan lignin terendah yaitu $22,4 \%$

\section{DAFTAR PUSTAKA}

Alimon, A.R. 2005. The nutritive value of palm kernel cake for animal feeds. Palm Oil Developments, vol. 40. Malaysian Palm Oil Board, Kuala Lumpur, Malaysia, pp. 12-14.

Blanchette R.A., K.R. Cease dan A.R. Abad. 1991. An evaluation of different forms 
of deterioration found in archaeological wood. Int Biodeter. 28:3-22.

Blanchette R.A. 1984. Screening wood decayed by white rot fungi for preferential lignin degradation. Appl Environ Microbiol. 48:647-653

Bonnarme. P and T.W. Jeffries. 1990. Mn(II) regulation of lignin peroxidases and manganese-dependent peroxidases from lignin-degrading white rot fungi. Appl Environ Microbiol. 56(1):210-217.

Broda, P., P.R.J. Birch, P.R. Brooks, P.F.G. Sims. 1996. Lignocellulose degradation by Phanerochaete chrysosporium : gene families and gene expression for a complex process. Molecul Microbiol. 19:923-932.

Brown, J.A., J.K. Glend, M.H. Gold. 1990. Manganese regulate expression of manganase peroxidase by Phanerochaete crysosporium. J Bacteriol. 172:31253130.

Chung, K.R. 2003. Involvement of calcium/calmodulin signaling in cercosporiumtoxin biosynthesis by Cercospora nicotienae. Apll Environ Microbial. 69:1187-1196.

Church, D.C., and W. G. Ponds. 1982. Basic Animal Nutrition and Feeding. 2nd Ed. Jhon Wiley and Sons. New York.

Crawford, R.L. 1981. Lignin Biodegradation and Transformation. New York: John Wiley and Sons.

Crueger, W. and A. Crueger. 1984. Biotecnology : A.Textbook of Industrial Microbiology. Sinauer Associates. Inc. Sunderland.

Dashban, M., H. Scrraft, W. Qin. 2009. Fungal bioconversion of lignocellulosic residues: Opportunities and perspective Int J Biol Sci. 5(6):578 -595.

de Koker, T.H., K.K. Nakasone, J. Haarhof. Jr.H.H. Burdsall, B.J.H. Janse. 2003. Phylogenetic relationship of the genus Phanerochaete inferred from the internal transcribed spacer region. Mycol Res. 107:1032-1040.

Febrina, D. 2014. Biodelignifikasi oleh kapang $P$. chrysosporium dengan penambahan mineral $\mathrm{Ca}$ dan pengaruhnya terhadap kandungan nutrien pelepah sawit sebagai salah satu upaya untuk menjamin ketersediaan pakan sepanjang waktu dengan menerapkan teknologi ramah lingkungan. Laporan Penelitian. Lembaga Penelitian dan Pengabdian Kepada Masyarakat. Uin Suska Riau. Pekanbaru.

Febrina, D., N. Jamarun, M. Zain., Khasrad and M. Rini. 2014. Biological delignification by Phanerochaete chrysosporium with addition of mineral $\mathrm{mn}$ and its effect on nutrient content of oil palm frond. The 16th AAAP Animal Science Congress November 1014, 2014. Yogyakarta, Indonesia. pp $1.723-1.726$

Hendriks, A.T.W.M., G. Zeeman. 2009. Pretreatment to enchance the digestibility of lignocellosic biomass. Bioresour Technol. 100:10-18.

Iconomou, D., K. Kandylis, C. Israilides and P. Nikokyris. 1998. Protein enchancement of sugar beet pulp by fermentation and estimation of protein degradability in the rumen of sheep. Small Rum. Res.27:55-61.

Imsya. A. 2013. Hasil biodegradasi lignoselulosa pelepah sawit (Elacis queneensis) oleh Phanerochaete chrysosporium sebagai antioksidan dan bahan pakan ternak. Disertasi. Sekolah Pascasarjana. Institut Pertanian Bogor. Bogor.

Jackson, S. L. And I. B. Heath. 1993. Roles of calcium ions in hyphal tip growth. Microbiol Rev.57:367-382.

Jager, A., S. Croan, T.K. Kirk. 1985. Production of ligninase and degradation of lignin in agitated submerged cultures 
of Phanerochaete chrysosporium. Appl. Environ Microbiol. 50:1274-1278.

Kapich, A.N., B.A. Prior, A. Botha, S. Galkin, T. Lundell, A. Hatakka. 2004. Effect of lignocellulose-containing submerged cultures of Phanerochaete chrysosporium ME-446. Enzyme Microbial. Technol. 34.187-195.

Kawamoto, H., W.Z. Mohamed, N.I.M. Sukur, M.S.M. Ali, Y. Islam, S. Oshio. 2001. Japan Agric. Res. Quart. 35. 195200.

Keller, F., J. Hamilton, Q. Nguyen. 2003. Microbial pretreatment of biomass. Appl Biochem Biotechnol.105:27-41.

Kementerian Pertanian. 2014. Statistik Pertanian 2014. Sutiyorini S, Waryanto B, editor. Jakarta (ID): Pusat Data dan Sistem Informasi Pertanian Kementerian Pertanian.

Kirk, T.K., E. Schultz, W.J. Connors, J.G. Zeikus. 1978. Influence of culture parameters on lignin metabolism by Phanerochaete chrysosporium. Arch. Microbiol.117.277-285.

Kirk, K.T., and H.M. Chang. 1990. Biotecnology in pulp and paper manufacture. New York. Butterworth-Heinemann.

Kumar, A. G., G. Sekaran., S. Krisnamoorthy. 2006. Solid state fermentation of Achras zapota lignocellulose by Phanerochaete chrysosporium. Bioresource Technology. 97:1521-1528.

Lymar, E.S., B. Li, V. Renganathan. 1995. Purification and characterization of a cellulose binding $\beta$ glucosidase from cellulose degrading culture of Phanerochaete chrysosporium. Appl Environ Microbiol. 61:2976-2980.

Lynd, L.R., P.J. Weimer, Zyl W.H. Van, I.S. Pretorius. 2002. Microbial cellulose utilization : fundamentals and biotechnology. Microbiol Mol Biol Rev.66: 506577.
Mariani. R. 2014. Evaluasi kecernaan in vitro fermentasi pelepah sawit dengan kapang Phanerochaete chrysosporium yang disuplementasi dengan mineral Mn. Tesis. Pascasarjana. Universitas Andalas. Padang.

May, R., P. Schroder dan H. Sandermann. 1997. Ex-situ process for treating PAHcontaminated soil with Phanerochaete chrysosporium. Environmental Sci. \& Technol. 31: 2626-2633.

Mc. Donald, P., R.A. Edwards, J.F.D. Greenhalgh and C.A. Morgan. 2010. Animal Nutrition. 7th Edition. Longman. Scientific and Technical John Willey and Sons. Inc. New York.

Nelson. 2011. Degradasi bahan kering dan produksi asam lemak terbang in vitro pada kulit buah kakao terfermentasi. Jurnal Ilmiah Ilmu-Ilmu Peternakan. XIV(1):44-50.

Ohkuma, M., M. Yoshima, J. Toru and K. Toshiaki. 2001. Lignin degradations and role of white rot fungi : study of an efficient symbiotic system in fungus growing termites and its application to bioremediation.RIKEN. Rev 42:39-42.

Perez, J., J. Munoz Dorado, T. de la Rubia, and Martinez. 2002. Biodegradation andbiological treatment of cellulosa, hemicellulosa and lignin: an overview. Int. microbiol. 5: 53-56.

Rahayu, S. 2014. Biodelignifikasi pelepah sawit menggunakan kapang Phanerochaete chrysosporium yang disuplementasi mineral $\mathrm{Ca}$ dan evaluasi kecernaan secara In vitro. Tesis. Pascasarjana. Universitas Andalas. Padang.

Rothschild, N., A. Levkowitz, Y. Hadar, C.G. Dosoretz. 1999. Manganese deficiency can replace high oxygen levels needed for lignin peroxidase formation by Phanerochaete chrysosporium. Appl. Environ. Microbiol. 65.483-488. 
Shi, J., M.S. Chinn, R.R. Sharma-Shivappa. 2008. Microbial pretreatment of cotton stalks by solid state cultivation of Phanerochaete chrysosporium. Bioresour Technol. 99: 6556-64.

Shi, J.G,. G.M. Zeng, X.Z. Yuan, F. Dai, J. Liu and X. H. Wu. 2006. The stimulative effects of surfactants on composting of waste rich in cellulose. Word $\mathrm{J}$ Microbiol Biotechnol 22-1121-1127.

Shi, J., R.R. Sharma-Shivappa. 2009. Microbial pretreatment of cotton stalk by cultivitation of P. chrysosporium. Bioreour Technol. 100:4388-6564.

Shroeder, J.W. 2004. Forage nutrition for ruminants. NDSU. Extention Service.

Silva, E.M., S.F. Martins and A.M.F. Milagres. 2008. Extraction of manganese peroxidase produced by Lentinula edodes. Bioresource Technology. 99: 2471-2475.

Singh, D., S. Chen S. 2008. The White-rot fungus Phanerochaete chrysosporium conditions for the production of lignin degrading enzymes. Appl Microbiol Biotechnol. 81:399-417.

Srebotnik, E., K.A. Jensen dan K.E. Hammel. 1994. Fungal degradation of recalcitrant nonphenolic lignin structure without lignin peroxidase. Proc. Natl. Acad. Sci. 91:12794-12797.

Sun, Y., J. Cheng. 2002. Hydrolysis of lignocellulosic materials for ethanol production : a review. Bioresour. Technol. 83.1-11.

Suparjo. 2010. Peningkatan kualitas nutrisi kulit buah kakao sebagai pakan secara bioproses dengan Phanerochaete chrysosporium yang diperkaya dengan ion $\mathrm{Mn} 2+$ dan $\mathrm{Ca} 2+$. Disertasi Sekolah Pascasarjana. Institut Pertanian Bogor. Bogor.

Sutardi, T. 1980. Ikhtisar ruminologi. bahan penataran kursus peternakan sapi perah di Kayu Ambon, Lembang. BPPLP-Dit, Jend. Peternakan-FAO.

Ürek, R. O., and N.K. Pazarlio`glu. 2005. Production and stimulation of manganese peroxidase by immobilized Phanerochaete chrysosporium. Process Biochemistry. 40:83-87.

Van Soest, P.J. 1994. Nutritional Ecology of The Ruminant. 2nd ed. Comstock Publishing Associates. A. Division of Cornell University Press. Ithaca and London.

Wan, C., Y. Li. 2012. Fungal pretreatment of lignocellulosic biomass Biotechnology Advances.30:1447-1457.

Widiyanto, E. Pangestu, Surahmanto, V.D. Yunianto, B.I.M. Tampoebolon and B.W.H.E. Prasetiyono. 2015. Effect of mineral supplementation and introduction of Setaria sphacelata Grass and Gliricidia sepium legume on productivity of kacang goat at Serang River Basin Upland Area, Central Java, Indonesia. Pakistan Journal of Nutrition. 14(8):440-446.

Wuyep, P.A., A.U. Khan, A.J. Nok. 2003. Production and regulation of lignin degrading enzymes from Lentinus squarrosulus (Mont) singer and Psathyrellaa troumbonata Pegler. African J. Biotechnol. 2(11):444-447.

Zahari, M.W., A.R. Alimon. 2005. Use of palm kernel cake and oil palm byproducts in compound feed. Palm Oil Developments, vol. 40. Malaysian Palm Oil Board,

Zeng G. M. Yu, Y. Cheng, D. Huang, J. Zhang, H. Huang, R. Jiang and Z. Yu. 2010. Effects of inoculan with Phanerochaete chrysosporium at various time points on enzyme activities during agricultural waste composting. Bioresour. Technol. 101 : 222-227.

Zhao, J., T.H. Koker, B.J.H. Janse. 1996. Comparative studies of lignin peroxidases and manganese-dependent 
peroxidases produced by selected white rot fungi in solid media. FEMS Microbiol. Lett.145.393-399.

Zhi, $\mathrm{Z}$ and $\mathrm{H}$. Wang. 2013. White-rot fungal pretreatment of wheat straw with
Phanerochaete chrysosporium for biohydrogen production: simultaneous saccharification and fermentation. Bioprocess Biosyst Eng. 